News, Notes and Queries

\title{
BRITISH SOCIETY FOR THE HISTORY OF MEDICINE SEVENTH BRITISH CONGRESS ON THE HISTORY OF MEDICINE
}

THE Seventh British Congress on the History of Medicine will be held in Churchill College, Cambridge, from 10-13 September 1969. This will be the third residential congress in the series, and those who attended the sixth congress in the University of Sussex in September 1967 will recall how successful and enjoyable that meeting was.

The subject chosen for the Congress theme is an important one, being 'Cambridge and its Contribution to Medicine'. A distinguished group of speakers, mostly drawn from Cambridge University, will discuss the role of their university and medical school in Anatomy and Physiology, Biochemistry, Nutrition, Genetics, and Clinical Medicine. The whole will provide a completely fresh and unparalleled historical survey of the development of the medical sciences in Cambridge. The final session, on the Saturday morning, will be devoted to the History of Medical Education in Cambridge.

Congress members and their guests have been invited to a reception by the Board of Governors of the United Cambridge Hospitals, of which the Chairman is Lord Todd (Wednesday, 10 September, 6-8 p.m.); and another by the Regius Professor of Physic, Professor J. S. Mitchell, C.B.E., F.R.S. (Thursday, 11 September, 6-8 p.m.).

The entire residential accommodation is provided in Churchill College and the scientific sessions will be held in the Wolfson Hall at the College. As this accommodation is strictly limited early application is recommended.

All correspondence concerning the Congress should be addressed to:

Dr. F. N. L. POYNTER

WeLlCOME INSTITUTE OF THE History OF MEDicine

183 Euston ROAD, LONDON, N.W.1.

\section{MUSEUM OF THE HISTORY OF MEDICINE AT THE UNIVERSITY OF THE WITWATERSRAND-JOHANNESBURG}

This museum, which to date is the first of its kind in the Republic of South Africa, is situated in the grounds of the South African Institute for Medical Research in the very heart of medical activities in the City of Johannesburg in very close proximity to the Johannesburg General Hospital, to the Medical School and various private medical institutions.

The prime object of the Museum is to collect and preserve all material which illustrates the history of medicine and its allied sciences, dentistry, pharmacy, etc., in general and of South Africa in particular. This material will be used for teaching purposes and for research. Lectures, films and exhibitions will continue to be arranged.

The Museum has acquired, since its establishment five years ago, a very large number of medical and surgical instruments and items of equipment of historic interest, several thousand reprints on historical medical subjects, many of which are illustrated. Its reference library grows apace. It has over 300 textbooks devoted 